УДК 636.2:619:616.569:619:616-036 (477.53-22)

(C) 2017

Передера С. Б., кандидат ветеринарних наук,

Колотій М. В., головний лікар ветеринарної медицини агрофірми «Маяк»,

Передера Ж. О., кандидат ветеринарних наук,

Щербакова Н. С., кандидат ветеринарних наук

Полтавська державна аграрна академія

\title{
МОНІТОРИНГ НЕКРОБАКТЕРІОЗУ ВЕЛИКОЇ РОГАТОЇ ХУДОБИ В АГРОФІРМІ «МАЯК» КОТЕЛЕВСЬКОГО РАЙОНУ ПОЛТАВСЬКОЇ ОБЛАСТІ
}

\section{Рецензент - доктор ветеринарних наук, професор С. М. Кулинич}

У статті наведені дані щодо моніторингу серед стада великої рогатої худоби тварин з патологією ураження копитець в агрофірмі «Маяк» за останні роки. Виявлено, щчо патологія копитецьь неінфекційного характеру становила до $30 \%$ від загальної кількості уражених копитецьь, а у $70 \%$ спостерігалось ураження копитець інфекиійної патології-некробактеріоз. Серед молодняку великої рогатої худоби 817-місячного віку некробактеріоз спостерігався у 2013 рочі у 3,6 \% тварин з 406, а у 2015 рочі - 2,9\% 3 617 тварин. Встановлено, щуо середній вік тварин, хворих на некробактеріоз, становить 6-7 років, з 939 хворих 190-20,2\%, а це-високопродуктивні тварини.

Ключові слова: некробактеріоз, моніторинг, хвороби кінцівок, інфекційна патологія кінцівок.

Постановка проблеми. Хвороби кінцівок у корів бувають часто й завдають відчутних збитків господарствам унаслідок зниження продуктивності хворих тварин, витрат на лікування, а у разі неефективності лікування частого їх вибракування. Особливо ця проблема загострилася в роки спеціалізації молочного скотарства через різку зміну умов годівлі та утримання тварин [2].

Високопродуктивні корови менше захищені від негативного впливу навколишнього середовища внаслідок виведення 3 молоком великої кількості елементів, потрібних організму для самозахисту. Власники тварин, оцінюючи генетичний потенціал корів голштинської породи, на жаль, забувають про необхідні для його реалізації умови, а саме збалансована за всіма компонентами годівля та належний ветеринарносанітарний догляд за тваринами. Саме тому в організмі тварин порушуються фізіологічні процеси, що проявляються різноманітними хворобами, особливо ураженнями кінцівок. До таких хвороб відноситься і некробактеріоз.

Аналіз основних досліджень і публікацій, у яких започатковано розв'язання проблеми. Некробактеріоз у великої рогатої худоби, поросят і курчат проявляється спорадично, але в умовах різкого зниження резистентності організму або значного порушення зоогігієнічних норм утримання й годівлі тварин можуть виникати тяжкі ензоотії і, навіть, епізоотії. Некробактеріоз може ускладнювати перебіг різних захворювань вірусної (ящур, віспа, пустульозний стоматит тощо) або гельмінтозної етіології. За несприятливих ветеринарно-санітарних умов некробактеріоз часто набуває стаціонарного характеру i може передаватися від одного виду тварин до іншого. Стаціонарності захворювання сприяє також тривале бактеріоносійство в разі хронічного перебігу хвороби, несвоєчасна ізоляція та лікування хворих тварин $[2,1]$.

Мета роботи - провести моніторинг стада великої рогатої худоби тварин хворих на некробактеріоз за останні роки.

Матеріали і методи дослідження. Епізоотологічні дослідження були проведені в агрофірмі «Маяк» Котелевського району, Полтавської області, водночас вивчалась ветеринарна звітність з 2008 року, мікробіологічні дослідження проводились у районній державній лабораторії ветеринарної медицини Котелевського району. Для підтвердження діагнозу на некробактеріоз готували по три мазка - відбитка з уражених тканин від кожної тварини і направляли до лабораторії. Також відбирали уражені тканини копитного рогу і направляли на бактеріологічні дослідження на виявлення збудника. Мазки висушували на повітрі, фіксували в полум'ї спиртівки і фарбували за Грамом. Далі досліджували під світловим мікроскопом.

Результати досліджень. Агрофірма «Маяк» Котелевського району, Полтавської області з 2008 була неблагополучна на некробактеріоз великої рогатої худоби. У 2010-2013 роках відмічалось підвищення захворюваності на некробактеріоз серед молодняку великої рогатої худоби із враженням кінцівок на некробактеріоз у вигляді спорадичних випадків. На даний час випадки некробактеріозу великої рогатої хвороби у господарстві спостерігаються у дорослих тварин так як існують 


\section{ВЕТЕРИНАРНА МЕДИЦИНА}

сприятливі умови для його виникнення у вигляді ензоотії: 1) наявність збудника у навколишньому середовищі (грунті); 2) зниження загальної резистентності організму тварин; 3) наявність травматизму кінцівок, що викликається утриманням тварин на бетонних полах тощо.

Провівши ретельний моніторинг хвороб кінцівок, найбільший пік захворюваності припав на 2013 рік - 20,2 \%. Після проведення ретельної ветеринарно-санітарних i лікувальних заходів відсоток захворюваності на некробактеріоз щодо основного стада МТФ-1 у 2014 та 2015 році знизився до 12,2 та 7,7 \% відповідно в порівнянні 3 2013 роком. Середній вік тварин вражених на некробактеріоз становить 6-7 років, а це високопродуктивні тварини.

Проаналізувавши патологію ураження копитець встановили, що патологія копитець неінфекційного характеру становила до $30 \%$ від загальної кількості уражених копитець, а у $70 \%$ спостерігалось ураження інфекційної патології некробактеріоз.

Захворювання починається 3 почервоніння шкіри міжкопитної щілини, тварини при цьому притримують уражену кінцівку у висячому положенні або спираються на зачіп, потім в області підошви і міжкопитної щілини, віночка, іноді зовнішніх рогових стінок копит з'являються гнійні поразки, що кровоточать далі з'являються гнійні рани, абсцеси, нориці. Водночас відзначають набряклість суглоба, фаланги копита, що підсилює кульгавість, сильну болючість, на тлі цього проявляється зниження продуктивності (маси тіла, надоїв та ін.). У разі подальшого розвитку патологічного процесу спостерігається ураження суглобових капсул і зв'язок, сухожиль, кісток. Процес може прийняти злоякісний характер, викликаючи флегмони і поразки верхніх су- глобів, до кульшового. Водночас температура тіла може підвищуватися у великої рогатої худоби до $40-42{ }^{\circ} \mathrm{C}$ або залишатися в межах норми.

Серед молодняку великої рогатої худоби 817-місячного віку некробактеріоз спостерігався у 2013 році 3,6\% 3406 тварин, а у 2016 році 1,6\% 3890 тварин. У тварин 3 некробактеріозним ураженням копитець спостерігались такі клінічні ознаки: кульгавість на одну або дві кінцівки; під час пальпації кінцівка була на дотик гаряча і болюча, відмічалось почервоніння; далі на місці первинного процесу ділянка гіперемії поступово розширювалась і ставала більш інтенсивно вираженою, з'являлося серозне виділення, яке швидко засихало, утворюючи на шкірі кірку. На основі клінічних ознак був поставлений попередній діагноз некробактеріоз кінцівок.

У мазках з патологічного матеріалу були виявлені довгі грамнегативні нитки, що складалися iз 60-80 члеників і не мали спор і капсул. За морфологічними ознаками був виявлений збудник некробактеріозу - Fusobacterium necrophorum.

\section{Висновки:}

1. Встановлено, що патологія копитець неінфекційного характеру, в агрофірмі «Маяк», становила до 30 \% від загальної кількості уражених копитець, а у $70 \%$ спостерігалось ураження інфекційної патології- некробактеріоз.

2. Середній вік тварин уражених на некробактеріоз становить 6-7 років.

3. Найбільший пік захворюваності на некробактеріоз серед молодняку великої рогатої худоби 8-17-місячного віку некробактеріоз спостерігався у 2013 році - 3,6 \% тварин 3406.

4. У 2016 році відмічається зниження захворюваності на некробактеріоз великої рогатої худоби більше ніж у два рази в порівнянні з 2013 роком по всім групам тварин.

Моніторинг хвороб кінцівок великої рогатої худоби

\begin{tabular}{|c|c|c|c|}
\hline Рік & $\begin{array}{c}\text { МТФ № 1 } \\
\text { (кільк. тв./хв. тв. - \%) }\end{array}$ & $\begin{array}{c}\text { МТФ № 2 } \\
\text { (кільк. тв./хв. тв. - \%) }\end{array}$ & $\begin{array}{c}\text { Годувальниця 2 } \\
\text { (кільк. тв./хв. тв. - \%) }\end{array}$ \\
\hline 2008 & $816 / 55-6,7 \%$ & $867 / 86-9,9 \%$ & - \\
\hline 2009 & $810 / 125-15,4 \%$ & $873 / 110-12,6 \%$ & - \\
\hline 2010 & $820 / 120-14,6 \%$ & $958 / 130-13,6 \%$ & - \\
\hline 2011 & $910 / 166-18,2 \%$ & $971 / 112-11,5 \%$ & $202 / 3-1,5 \%$ \\
\hline 2012 & $930 / 175-18,8 \%$ & $947 / 90-9,5 \%$ & $406 / 15-3,7 \%$ \\
\hline 2013 & $939 / 190-20,2 \%$ & $882 / 111-12,6 \%$ & $539 / 14-2,6 \%$ \\
\hline 2014 & $899 / 110-12,2 \%$ & $916 / 90-9,8 \%$ & $617 / 18-2,9 \%$ \\
\hline 2015 & $909 / 70-7,7 \%$ & $980 / 92-9,4 \%$ & $890 / 15-1,6 \%$ \\
\hline 2016 & $650 / 15-2,3 \%$ & $1200 / 65-5,4 \%$ & \\
\hline
\end{tabular}




\section{ВЕТЕРИНАРНА МЕДИЦИНА}

\section{БІБЛІОГРАФІЯ}

1. Каришева А. Ф. Спеціальна епізоотологія : підручник / А. Ф. Каришева. - К. : Вища освіта, 2002. $-703 \mathrm{c}$.

2. Марченко О. М. Некробактеріоз великої рогатої худоби (особливості перебігу, біологічні властивості F.necrophorum та ефективність вак-

цинопрофілактики) / О. М. Марченко : дис. ... к.вет.н. : 16.00.08. - К. : УААН, Інститут ветеринарної медицини, 2003. - 177 арк. : рис., табл. Бібліогр. : арк. 129-153. 